\title{
From sambaquis (shell mounds) to plastic debris: a summary of the geological imprint of human occupation in the coast of São Paulo (Southeast Brazil)
}

\section{Dos sambaquis aos fragmentos plásticos: um resumo do registro geológico da ocupação humana no litoral de São Paulo (Sudeste do Brasil)}

\author{
Alynne Almeida Affonso ${ }^{\text {ac }}$, Michel Michaelovitch de Mahiques ${ }^{\text {ad }}$, Paulo Alves de Lima Ferreira ${ }^{\text {ae }}$ \\ Diana Melo Italiani ${ }^{\text {bf }}$, Cristina Celia Martins ${ }^{\text {ag }}$, Javier Alcántara-Carrióah, \\ Rubens Cesar Lopes Figueira ${ }^{\text {ai }}$, Renata Hanae Nagai ${ }^{\mathrm{bj}}$
}

${ }^{a}$ Instituto Oceanográfico (Universidade de São Paulo), ${ }^{\text {b} C e n t r o ~ d e ~ C i e ̂ n c i a s ~ d o ~ M a r ~(U n i v e r s i d a d e ~ F e d e r a l ~ d o ~ P a r a n a ́) ~}$

calynnealmeidaaffonso@gmail.com, ${ }^{\mathrm{d} m a h i q u e s @ g m a i l . c o m, ~}{ }^{\mathrm{p}}$ paulo.alves.ferreira@usp.br, ${ }^{\mathrm{f} d i a n a j g d @ g m a i l . c o m}$, scmartins.cristina@gmail.com, hjavier.alcantara@usp.br, ${ }^{i}$ rfigueira@usp.br, ${ }^{j}$ renatanagai@gmail.com

\begin{abstract}
In this work, we present a brief revision of the geological evidence of human activities in the coast of São Paulo (Southeast Brazil), from pre-historical times to the present. We analyze case studies in different sectors of the coast, identifying the main historical causes that resulted in environmental changes with their consequent imprint in the sedimentary column. There was a south-to-north trend in the occupation at the colonization period (1500 onwards), essentially determined by differences in the geomorphology of the area. Finally, the accumulation of artificial radionuclides and plastic debris in the sediments is discussed.
\end{abstract}

Keywords: Human occupation; coastline; SE Brazil

\section{Resumo}

Neste trabalho, apresentamos uma breve revisão das evidências geológicas das atividades humanas no litoral de São Paulo (Sudeste do Brasil), desde os tempos pré-históricos até o presente. Analisamos estudos de caso em diferentes setores da costa, identificando as principais causas históricas que resultaram em mudanças ambientais com sua consequente impressão na coluna sedimentar. Havia uma tendência sul-norte na ocupação no período de colonização (1500 em diante), essencialmente determinada por diferenças na geomorfologia da área. Finalmente, o acúmulo de radionuclídeos artificiais e detritos plásticos nos sedimentos é discutido.

Palavras-chave: Ocupação humana; litoral; SE do Brasil

\section{Introduction}

The definition of the beginning of the Anthropocene in coastal areas is undoubtedly chronologically much younger than the human occupation of the coasts itself (Menzel, 1959; Kaplan, 1980; Stringer, 2000). Actually, the definition of the base of this new epoch is, somehow, still a matter of debate, since the geological/ geochemical evidence of the end of the Holocene can be interpreted in different ways (Steffen et al., 2007; Leorri et al., 2014; Irabien et al., 2015; Zalasiewicz et al., 2015; Waters et al., 2016). It is worth observing that in different coastal and marine areas the evidence goes back to pre-Industrial ages (Crutzen and Steffen, 2003; Martins et al., 2013; Leorri et al., 2014; Irabien et al., 2015).

In this paper, we present a brief review of the geological imprint of the human occupation of the coast of São Paulo (Southeast Brazil), an area of a relatively recent historical occupation, caused by different economic activities, but with geological evidence of pre-Columbian settlings. The main aim of this work is to recognize when, why and how the geological records show evidence of the beginning of the Anthropocene in this coastal area.

\section{Area of Study}

The area of study corresponds to the coast of São Paulo, a part of the arc-shaped section of the Brazilian margin known as São Paulo Bight (Zembruscki, 1979) (figure 1). This coastal sector has been divided into different forms. According to Muehe (1998), it is divided into two different compartments, the Northern Crystalline Scarps Littoral and the Coastal Plains and Estuaries Littoral, the difference between them being essentially related to the position of the Serra do Mar mountain chain from the coast. More recently, in a review of the beach systems and considering a more complex morphology, de Mahiques et al. (2016b) divided the coast into six sectors, considering not only 
the position of the Serra do Mar but also the orientation of the coastline and incident wave dynamics.

The presence of the Serra do Marmountain chain controls the extent of the drainage basins and, consequently, in the coastal areas, the magnitude of coastal plains, estuaries and associated environments. This geomorphological control was one of the original causes for the differential occupation of the coast, in historical times (Bueno, 2009a; Cardoso and Ricci, 2013).

There are three hydrographic basins, Ribeira de Iguape, Santos Lowlands and Northern Coast, the first being the most important, with an area of approximately $17,000 \mathrm{~km}^{2}$. The climate is essentially tropical and humid, with high precipitation, which can reach values as high as $4,000 \mathrm{~mm} /$ year.

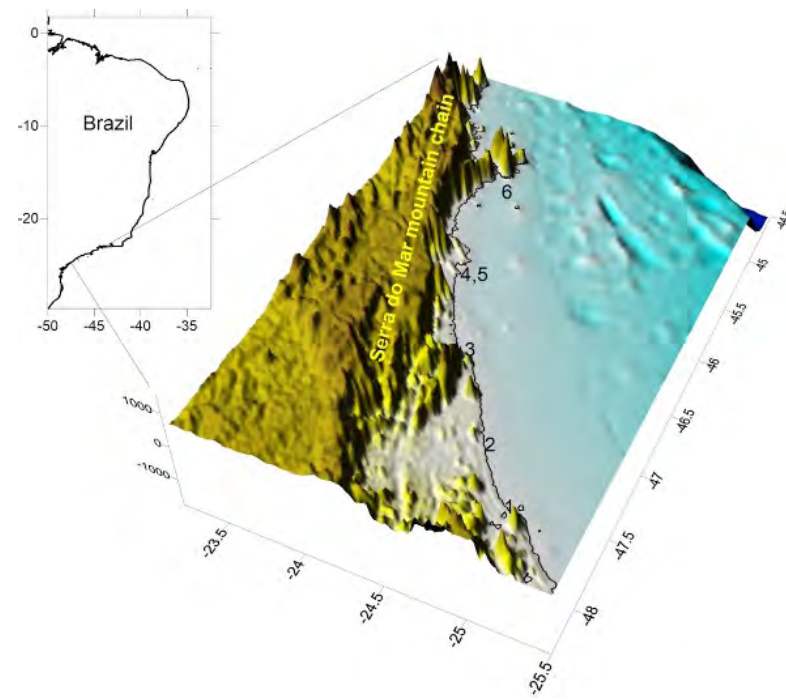

Figure 1: Digital elevation model of the study area, indicating the approximate location of the Serra do Mar Mountain chain. Numbers refer to cities cited in the text: 1. Cananeia, 2. Iguape, 3. Itanhaem, 4, São Vicente, 5. Santos, 6. São Sebastião

\section{Sambaquis}

Sambaquis (shell mounds) are a type of pre-historical archaeological site which is frequent along the Brazilian territory (Figuti, 1993). They consist of mound-shaped forms, mainly composed of shells, together with fishbones and, eventually, evidence of funerals of prehistorical inhabitants. Their ages range from about 10,000 yr BP to 1,000 yr BP (Figuti, 1993; Neves et al., 2005; Bueno and Dias, 2015), the oldest corresponding to the fluvial ones. A relatively outdated record of coastal sambaquis, in part of the coast of São Paulo, indicates non-calibrated radiocarbon ages between ca. 6,000 and 1,500 yr BP (Uchoa and Garcia, 1983) (figure 2).

Sambaquis have been widely used as direct indicators of Holocene sea-level changes, especially on the southern and south-eastern coast of Brazil (Martin et al., 1986). Nevertheless, its assumption as an unambiguous marker of sea-level must be analyzed with caution (Scheel-Ybert et al., 2009).

Despite their importance for archaeological and anthropological studies, there are many sambaquis that have been destroyed throughout historical times, the reasons varying from direct building of houses on top of them to mining of carbonate shells to further calcination and cement manufacturing.

According to Wichers (2010), there were 235 registered sambaquis in São Paulo; indeed, they represent the first geological evidence of human occupation and, despite their localized character, sambaquis corresponded to the first modification of the coastal landscape.
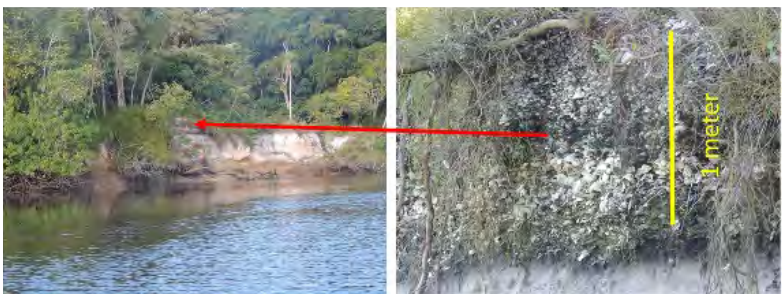

Figure 2: (Left). General view of the Sambaqui Boguassu (Ilha Comprida, São Paulo). (Right). Detail of the same sambaquis, showing conspicuous stratification, marked by differences in the mollusk assemblages.

\section{Historical times}

The coast of São Paulo was reached for the first time during the Portuguese expedition led by Amerigo Vespucci, in 1502. Most of the Portuguese toponymies of the coast are derived from that first expedition and the following exploratory surveys (Bueno, 2009b) (figure 3). In fact, the first three villages in Brazil (Cananeia, São Vicente, and Itanhaém) are located in the coast of São Paulo, and the village of São Vicente was the base of its homonymous hereditary captaincy (Cintra, 2015). As a rule, colonization started in the southern and central coast, where the extension of lowlands favored human occupation.

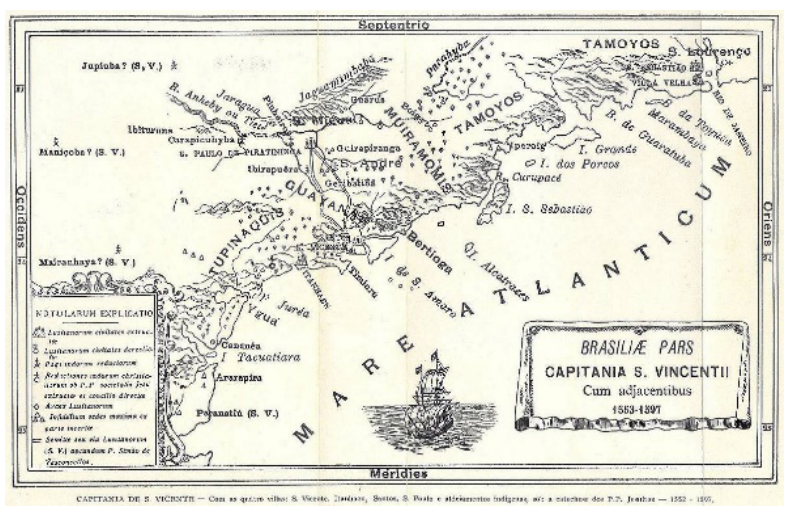

Figure 3: Reproduction of the map of the São Vicente Captaincy 1553-1597 (no author). Most of the present toponymy of the coast is already shown on this map. This map was originally presented by Calixto (1927). Image available at http://www.novomilenio.inf.br

Unlike Spanish America, the land colonized by the Portuguese offered natural goods, like Brazil wood, animals and agricultural products.

The reason for the foundation of the first villages in the area of São Vicente and Santos was strategic though since the topography of the islands (occupied by mountains and mangroves) was not propitious to extensive agriculture or human occupation. The geography of the site offered, as 
noted by colonizers, a natural fortress against enemies, and a natural port for vessels (Katinsky, 1999; Tulik and Roque, 2003; Gonzalez, 2007).

The beginning of the occupation of the territory was related to the necessity for the Portuguese crown to ensure the ownership of the newly discovered land. Its densification, especially in the village of São Vicente, was based on the development of sugarcane plantations and the establishment of sugarcane mills (Andreata, 1999). Posteriorly, the São Vicente and Santos villages served as a base for the troops who moved to the ancient village of São Paulo and, from there, to the interior of the wild country (Bueno, 2009a).

However, this first phase of the colonization did not leave significant imprints in the geological record. It is possible that the only exception is the tsunami that occurred in 1541 at the São Vicente village. Although there are no reliable records, it is known that the old village of São Vicente was destroyed and the local geography has changed due to this event. Therefore, the most effective approach for the investigation of the anthropogenic imprint of humans on the environment of Santos Lowlands in the $16^{\text {th }}, 17^{\text {th }}$ and $18^{\text {th }}$ centuries, are related with the analysis of historical documents and archaeological evidence.

\section{The Valo Grande case}

The Valo Grande ("Big Scour") probably consists of the oldest and more emblematic evidence of an anthropogenic action, with a significant change in the geological record of the coast of São Paulo, and with environmental consequences that remain today.

The Valo Grande is an artificial channel, which opened in 1827 and ended in 1852. Originally named Valo do Rocio, it aimed to directly connect the Ribeira River to the harbor of Iguape, at that time an important place for the export of agricultural goods, and located in the interior of a lagoon system, the Cananeia-Iguape Lagoon (De Mahiques et al., 2014).

The channel was excavated over unconsolidated sands, which were rapidly eroded at a rate up to 4 meters per year. From the original dimensions of 4.4 meters wide per 2 meters the channel presently shows widths of approximately 250 meters per depths of about 7 meters. Nowadays, about $60 \%$ of the freshwater and suspended sediments carried by the Ribeira River, the most important coastal river in São Paulo, reach the lagoonal system, with a consequent modification of environmental conditions (Martinez et al., 2013) and intense siltation (De Mahiques et al., 2014), forming several islands at the mouth of the artificial channel (figures 4 and 5).

Furthermore, due to a $\mathrm{Pb}$-mining activity that lasted from 1945 to 1995 in the upstream area of the Ribeira River, the lagoon system received contaminated sediments, with enrichment factors as high as 20 times the natural regional background (de Mahiques et al., 2012) (figure 6). Nowadays, despite the cessation of the mining activities, the system still receives significant quantities of metalenriched sediment since the mining debris are still deposited in the margin of the river (Tramonte et al., 2015).

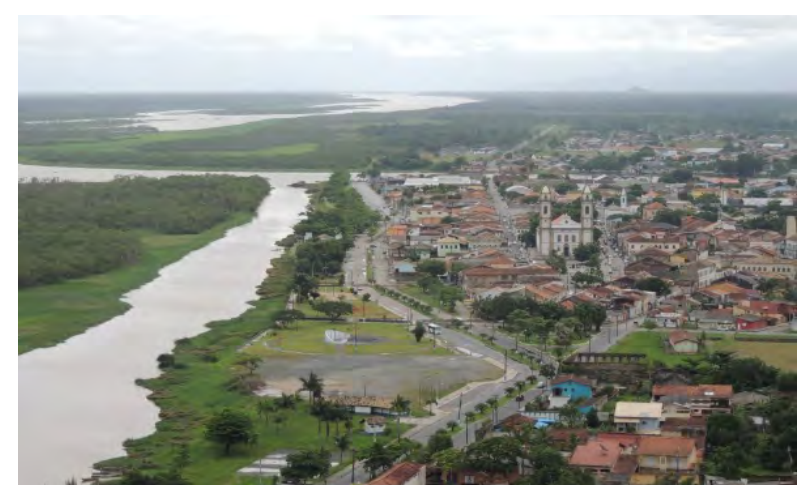

Figure 4: Islands formed at the mouth of the Valo Grande artificial channel, as a result of intense siltation in the area (Photo by Michel M Mahiques)

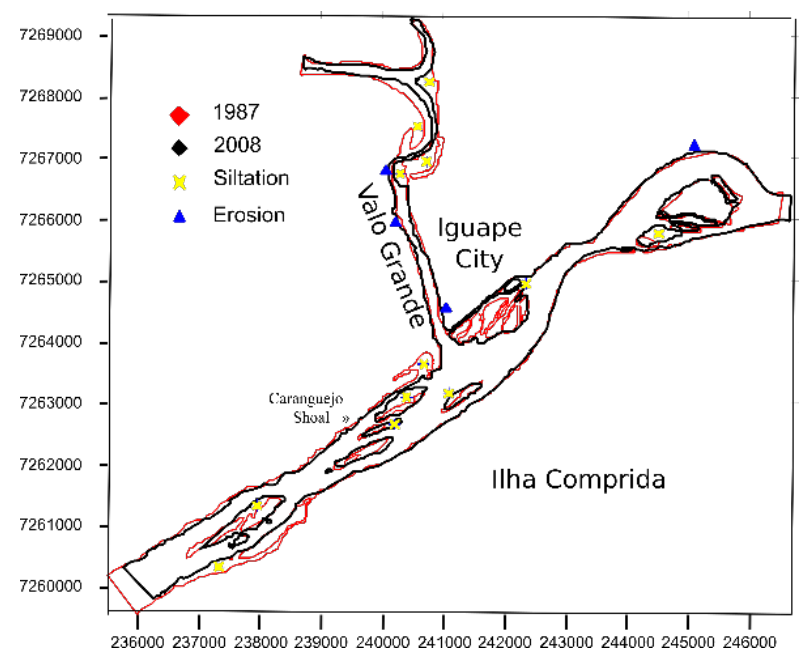

Figure 5: Coastline changes between 1987 and 2008, associated with the opening of the Valo Grande artificial channel. A series of islands were developed as a result of intense siltation at the channel's mouth

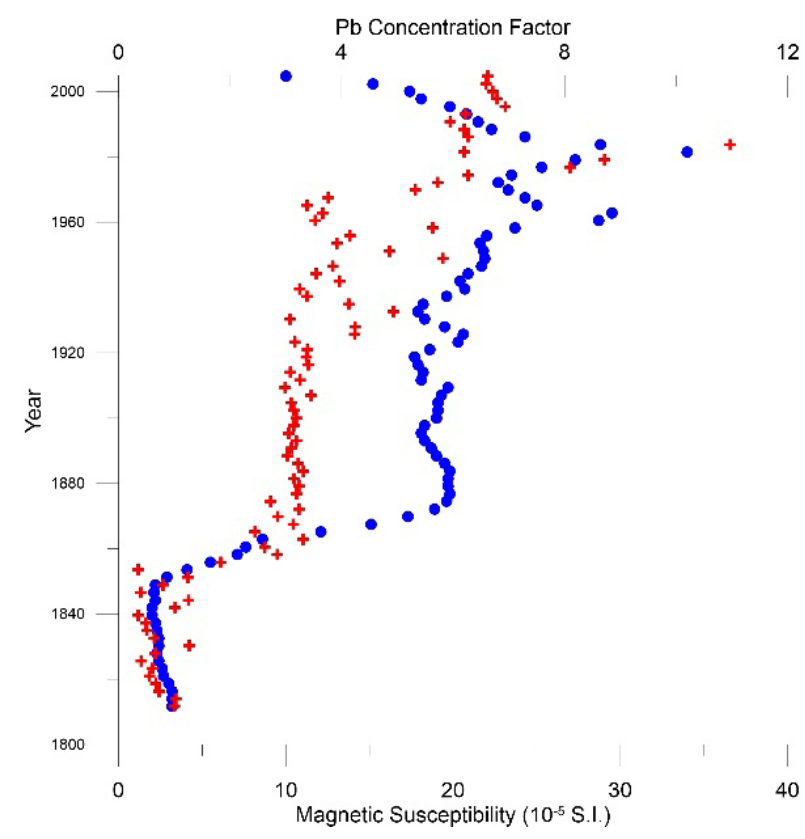

Figure 6: Variations of Magnetic Susceptibility (blue dots) and $\mathrm{Pb}$ Concentration Factor (red crosses) along time, in a core collected in the Cananeia-Iguape system, in the vicinities of the mouth of the Valo Grande, indicating a significant change in sediment properties just after the opening of the artificial channel, in 1852. Chronology was established via ${ }^{210} \mathrm{~Pb}$ gamma-ray spectrometry. 


\section{The Santos Lowlands ("Baixada Santista") and Santos Harbour}

\section{$16^{\text {th }}, 17^{\text {th }}$ and $18^{\text {th }}$ century}

The village of Santos was one of the first founded by Portuguese during the hereditary captaincies period. From the first phase of the São Vicente captaincy one of the most conspicuous archaeological evidences corresponds to the ruins of sugar mills (Andreata, 1999), although there are also remnants from the $16^{\text {th }}$ century in the "Parque das Naus" (Ships Parks, in free translation) (Tulik \& Roque, 2003).

It is believed that there existed at least six sugar mills in the first half of $16^{\text {th }}$ century in Santos Lowlands, and none of these survived to the present day, except for only just a few material records left. The decline and abandonment of the mills are probably associated with the decline of the sugar production and further impoverishment of the village (Reis, 1999). Also, pirate attacks, fires and natural disasters, along with the intense pressure of the occupation contributed to the destruction of archaeological heritage (Tulik \& Roque, 2003). Historical, descriptive documents and cartographic material are the keys to understand the impacts to the environment at the colonization period.

The São Jorge dos Erasmos mill presents the only remaining ruins from the period when sugar industry was essential to the economy of São Vicente captaincy. It was functional until the $18^{\text {th }}$ century and produced sugar cane for exportation during its operational peak $\left(16^{\text {th }}\right.$ and $17^{\text {th }}$ century) and brown sugar and cane liquor after the decline of the sugar industry in the south coast of São Paulo (Andreata, 1999) (figure 7).

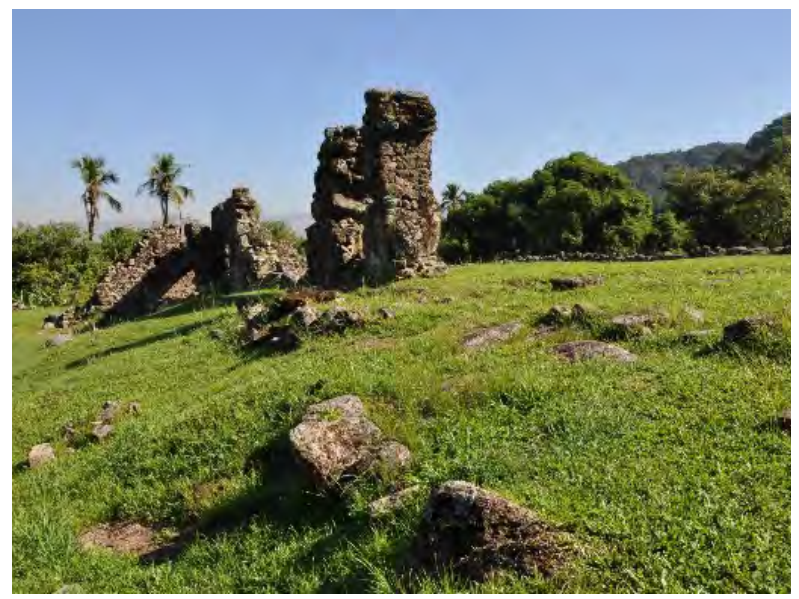

Figure 7: Remains of ruins - São Jorge dos Erasmos mill (Courtesy Monumento Nacional Ruínas Engenho São Jorge dos Erasmos PRCEU - USP)

The site presents itself poorly maintained and was the subject of excavations and archaeological research in the last 20 years. The results from these surveys include a cemetery with human bones from different individuals, archaeological evidence from the architecture of the buildings and from everyday use parts, as well as from instruments of extraction and production of natural goods (Morais et al., 2005).
Recently, an archaeological find during improvement works for the transport network revealed more than 300 fragments of objects dated from the $18^{\text {th }}$ century (Rossi, 2014.).

The maritime archaeological records in the Santos port also might present great potential in the attempts to understand the anthropological impacts in the study area. However, the investigation of archaeological attributes is focused mainly in the terrestrial areas of Santos. There are incipient initiatives of the survey in the estuary and channels of the port, and some archaeological research is already occurring in some sites near the port area (Gonzales, 2007).

\section{$19^{\text {th }}$ and $20^{\text {th }}$ Century}

The development of the Santos Lowlands increased dramatically in the second half of the $19^{\text {th }}$ century, after the construction of a railway that connected the coast with the plateau and permitting the transport of coffee, one of the main economic goods of the former Brazilian empire (Faria, 2015). In 1892 the first 200 meters of wharfs were completed, a length that reached almost 5,000 meters by 1910 . Urban modifications in Santos city were also made in the first decade of the $20^{\text {th }}$ century, including the construction of a series of drainage channels, which remain active today.

The most severe environmental impacts in the area started in the $1950 \mathrm{~s}$, with the construction of a steel plant and the first petrochemical industrial pole of Brazil, both in the city of Cubatão, located close to Santos, at the base of the Serra do Mar mountain range. The lack of environmental regulations at that time transformed the area into the most polluted zone of Brazil, with severe effects on health (Böhm et al., 1989; Jasinski et al., 2011), the pollutants being directly disposed in the soils and rivers or via atmosphere (Vautz et al., 2003).

As a result of this intense industrial and harbour activity, the modifications on sediment dynamics and record are observed in different ways, either on macro constituents (Berbel et al., 2015), metals (Cesar et al., 2006) and different types of hydrocarbons (Martins et al., 2007; Martins et al., 2010, 2011). Analysis of the sedimentary column of estuarine areas may reveal a history of human impacts and their peaks.

Analysis of ${ }^{210} \mathrm{~Pb}$ concentrations in marine core samples allows to rebuilt depositional records of the temporal variation from sedimentation rates on the continental shelf. Altogether with magnetic susceptibility, which is a method that was used to measure the magnetic signature of anthropogenic particles, it is possible to map the main polluting sources in an area. Fukumoto (2007) analyzed three core samples near sources of pollution at the Santos Lowlands. The author measured the Magnetic Susceptibility using a Bartington MS2C profiler, and the ${ }^{210} \mathrm{~Pb}$ concentrations were obtained by the emission of its gamma rays. There are peaks of geochemical anomalies at the beginning of the $1970 \mathrm{~s}$, related to 
the expansion of the Industrial Complex of Cubatão and the increase of population density around the high estuary (Fukumoto, 2007) (figure 8).

It is worth noting that anthropogenic compounds have also been identified in the adjacent shelf sediments (de Mahiques et al., 2016a).

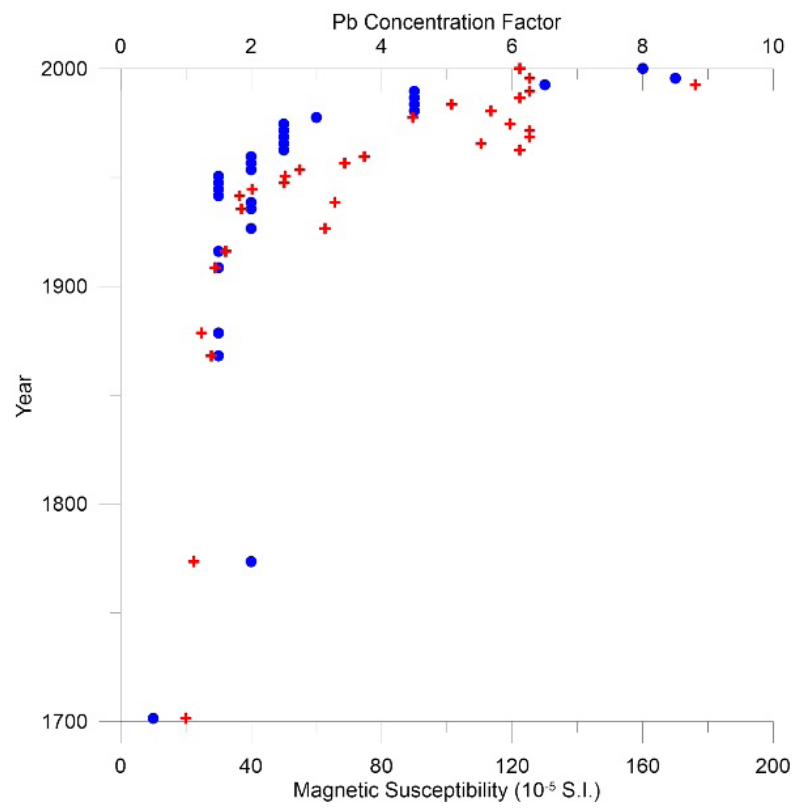

Figure 8: Variations of Magnetic Susceptibility (blue dots) and $\mathrm{Pb}$ Concentration Factor (red crosses) along time, in a core collected in the Santos Lowlands, in the vicinities of Santos harbor, indicating a significant change in sediment properties beginning in the first half of the 20th Century. Chronology was established via ${ }^{210} \mathrm{~Pb}$ gammaray spectrometry, combined with ${ }^{137} \mathrm{Cs}$ fallout peak of 1963

\section{Northern Coast}

The Northern Coast was the area with the later occupation, essentially dependent on the development of tourism, which started in the 1940s and 1950s (Cardoso and Ricci, 2013). Due to the proximity of the scarps of the Serra do Mar mountain range and the consequent difficulties in transport, the area was relatively unexplored until the second half of the $20^{\text {th }}$ century and experienced a decrease in its population during that period.

In this area, a more intense anthropogenic action occurred in the São Sebastião Channel, in which the construction of a harbour and an oil terminal, in the 1960s and 1970s led to several changes in the coastal landscape (Cunha, 2003) and the accumulation of petroleum hydrocarbons in the sediments of the coast and adjoining continental shelf (Zanardi et al., 1999).

As a consequence of the tourism development, and due to the geomorphologic characteristics, the Northern Coast experienced an increase in nautical activities, especially after the decade of 1970 . Because of the building of marinas and other nautical structures, several areas were subject to changes in the water circulation and sediment dynamics, leading to modifications in the sedimentary column. Unpublished data (AlbergariaBarbosa et al., 2011) present an example of intensive changes in sediment characteristics in one of those areas.

\section{Artificial Radionuclides}

As a result of the global fallout, the coastal sediments off São Paulo exhibit measurable levels of artificial radionuclides (Saito et al., 2001; Figueira et al., 2003; Figueira et al., 2006; Ferreira et al., 2016). The main methods to evaluate radionuclides on the studies mentioned above consisted on gamma-ray spectrometry (Saito et al., 2001; Figueira et al., 2006), alpha spectrometry (Figueira et al., 2003; Figueira et al., 2006) and ICP-OES (inductively coupled plasma-optical emission spectrometry) technique (Figueira et al., 2016). None of the artificial radionuclides measured present contamination levels (Santos et al., 2008) but, indeed, 1963 activity ${ }^{137} \mathrm{Cs}$ is being used as an independent tracer for recent sedimentary processes (Ferreira et al., 2016).

\section{Plastics}

Plastic debris is one of the main environmental concerns in marine studies and is being considered as one of the potential proxies for the beginning of the Anthropocene (Zalasiewicz et al., 2016). As well as in other coastal areas plastic debris causes severe problems to the marine fauna (Ivar do Sul and Costa, 2007). The study on plastic in the coast of São Paulo is still incipient, most of the work related with the accumulation of plastic pellets in beach sediments and their potential of accumulation of anthropogenic hydrocarbons (Fisner et al., 2013a; Fisner et al., 2013b). Nevertheless, plastic pellets are accumulating in the sedimentary column, becoming more and more representative as a fraction of beach sediments (Turra et al., 2014). The authors cited above followed UNEP (United Nations Environment Programme) protocols and guidelines for the samples acquisition, and analytical procedures and statistical tests were applied to obtain concentrations of plastic.

\section{Summary}

The coast of São Paulo has been occupied since pre-historical times, and its first inhabitants left geological imprints from their presence in this sector of the Brazilian littoral. After a hiatus of centuries, the effective colonization and consequent modifications of the environment started at the beginning of the $19^{\text {th }}$ century, in a general trend from the south to the north, the reasons for this is the geomorphological control, especially the location of the coastline regarding the Serra do Mar mountain chain.

The geological record of the human occupation is associated with different economic activities, mining in the south, industries and harbor in the Santos Lowlands and tourism in the north. First imprints of these activities date back to the beginning of the $19^{\text {th }}$ century.

Finally, it is worth noting that, if artificial radionuclides do not represent a big environmental issue in the present times, the accumulation of plastic debris may be an important concern along the coast, especially beaches. 


\section{Acknowledgments}

Thanks are due to Prof Marisa Coutinho Afonso (Museum of Archaeology and Ethnology of the University of São Paulo - MAE/USP), who provided valuable information about sambaquis. The Monumento Nacional Ruínas Engenho São Jorge dos Erasmos - PRCEU - USP provided fantastic images of the ruins. Mr. Carlos Pimentel (http://www.novomilenio. inf.br) authorized the utilization of the historical map. MMdeM acknowledges CNPq and FAPESP for financial support in different research projects. The authors acknowledge Mr. Kyle Flavin, for the revision of the text. This work has been developed in the context of Project PVE 047 2013/CAPES ("A Terra, o Mar e o Homem no estado de Santa Catarina: visões retrospectivas e prospectivas").

\section{References}

Albergaria-Barbosa, A. C. R., Alves, D. P. V., Baldassin, P., Bícego, M. C., Camargo, J. M., Coelho, L. H. F., Felix, C., Figueira, R. C. L., Freitas, F. S., Lourenço, T. S., Montone, R. C., Nagai, R. H., Santa-Cruz, J. S., Sousa, P. H. G. O., Stein, C. E., Yamashita, C., Yokoyama, C. K., and de Mahiques, M. M. 2011. Impacts of marina constructions over the depositional conditions in the Saco da Ribeira, Ubatuba-SP, Santos, 1-5.

Andreata, M. D. 1999. Engenho São Jorge dos Erasmos: Prospecção arqueológica, histórica e industrial, Revista USP, 41, 28-47.

Berbel, G. B., Favaro, D. I., and Braga, E. S. 2015. Impact of harbour, industry and sewage on the phosphorus geochemistry of a subtropical estuary in Brazil, Mar Pollut Bull, 93, 44-52.

Böhm, G. M., Saldiva, P. H. N., Pasqualucci, C. A. G., Massad, E., Martins, M. d. A., Zin, W. A., Cardoso, W. V., Criado, P. M. P., Komatsuzaki, M., Sakae, R. S., Negri, E. M., Lemos, M., Capelozzi, V. d. M., Crestana, C., and Silva, R. d. Biological effects of air pollution in São Paulo and Cubatão, Environmental Research, 49, 208-216

Bueno, B. P. S. 2009a. Dilatação dos confins: caminhos, vilas e cidades na formação da Capitania de São Paulo (1532-1822), Anais do Museu Paulista: História e Cultura Material, 17, 251294.

Bueno, B. P. S. 2009b. Do borrão às aguadas: os engenheiros militares e a representação da Capitania de São Paulo, Anais do Museu Paulista: História e Cultura Material, 17, 111-153.

Bueno, L. and Dias, A. 2015. Povoamento inicial da América do Sul: contribuições do contexto brasileiro, Estudos Avançados, 29, 119-147.

Cardoso, B. B. V. and Ricci, F. 2013. O desenvolvimento tardio no Litoral Norte de São Paulo: influência da infra-estrutura de transportes - Século XVIII a 1960, Revista Ciências Humanas, UNITAU, 6, 74-88.

Cesar, A., Pereira, C. D. S., Santos, A. R., Abessa, D. M., fernández, N., Choueri, R. B., and DelValls, T. A. 2006. Ecotoxicological assessment of sediments from the Santos and São Vicente estuarine system- Brazil, Brazilian Journal of Oceanography, $54,55-63$.

Cintra, J. P. 2015. As capitanias hereditárias no mapa de Luís Teixeira, Anais do Museu Paulista: História e Cultura Material, $23,11-42$.

Crutzen, P. J. and Steffen, W. 2003. How Long Have We Been in the Anthropocene Era?, Climatic Change, 61, 251-257.

Cunha, Í. 2003. Conflito ambiental em águas costeiras: relação porto - cidade no Canal de São Sebastião, Ambiente \& sociedade, 6.
De Mahiques, M. M., Figueira, R. C., Alves, D. P., Italiani, D. M., Martins, C. C., and Dias, J. M. 2014. Coastline changes and sedimentation related with the opening of an artificial channel: the Valo Grande Delta, SE Brazil, An Acad Bras Cienc, 86, 1597-1607.

de Mahiques, M. M., Figueira, R. C. L., Salaroli, A. B., Alves, D. P. V., and Gonçalves, C. 2012. 150 years of anthropogenic metal input in a Biosphere Reserve: the case study of the CananéiaIguape coastal system, Southeastern Brazil, Environmental Earth Sciences, 68, 1073-1087.

de Mahiques, M. M., Hanebuth, T. J. J., Martins, C. C., MontoyaMontes, I., Alcántara-Carrió, J., Figueira, R. C. L., and Bícego, M. C. 2016a. Mud depocentres on the continental shelf: a neglected sink for anthropogenic contaminants from the coastal zone, Environmental Earth Sciences, 75.

de Mahiques, M. M., Siegle, E., Alcántara-Carrió, J., Silva, F. G., Sousa, P. H. O., and Martins, C. C. 2016b. The beaches of the State of São Paulo. In: Brazilian Beach Systems, Short, A. D. and Klein, A. H. F. (Eds.), Springer International Publishing, Cham, Switzerland.

Faria, T. J. P. 2015. Os projetos e obras do engenheiro Saturnino de Brito e mudança na paisagem urbana, Geografia Ensino \& Pesquisa, 19, 115-122.

Ferreira, P. A. d. L., Figueira, R. C. L., Siegle, E., Asp Neto, N. E., Martins, C. d. C., Schettini, C. A. F., Maciel, P. M., GarcíaRodriguez, F., and Mahiques, M. M. d. 2016. Using a cesium-137 ( $137 \mathrm{Cs}$ ) sedimentary fallout record in the South Atlantic Ocean as a supporting tool for defining the Anthropocene, Anthropocene, 14, 34-45.

Figueira, R. C., Tessler, M. G., de Mahiques, M. M., and Cunha, II: 2006. Distribution of $137 \mathrm{Cs}, 238 \mathrm{Pu}$ and $239+240 \mathrm{Pu}$ in sediments of the southeastern Brazilian shelf-SW Atlantic margin, Sci Total Environ, 357, 146-159.

Figueira, R. C. L., Furtado, V. V., Tessler, M. G., and Cunha, I. I. L. 2003. Níveis de Pu-238 e Pu- 239+240 em amostras de sedimento marinho da costa sul do Brasil, Revista Brasileira de Oceanografia, 51, 55-62.

Figuti, L. 1993. O homem pré-histórico, o molusco e o sambaqui: considerações sobre a subsistência dos povos sambaquieiros, Revista do Museu da Arqueologia e Etnologia, 3, 67-80.

Fisner, M., Taniguchi, S., Majer, A. P., Bicego, M. C., and Turra, A. 2013a. Concentration and composition of polycyclic aromatic hydrocarbons (PAHs) in plastic pellets: implications for smallscale diagnostic and environmental monitoring, Mar Pollut Bull, $76,349-354$

Fisner, M., Taniguchi, S., Moreira, F., Bicego, M. C., and Turra, A. 2013b. Polycyclic aromatic hydrocarbons (PAHs) in plastic pellets: variability in the concentration and composition at different sediment depths in a sandy beach, Mar Pollut Bull, 70, 219-226.

Irabien, M. J., García-Artola, A., Cearreta, A., and Leorri, E. 2015. Chemostratigraphic and lithostratigraphic signatures of the Anthropocene in estuarine areas from the eastern Cantabrian coast (N. Spain), Quaternary International, 364, 196-205.

Ivar do Sul, J. A. and Costa, M. F. 2007. Marine debris review for Latin America and the wider Caribbean region: from the 1970s until now, and where do we go from here?, Mar Pollut Bull, 54, 1087-1104.

Jasinski, R., Pereira, L. A. A., and Braga, A. L. F. 2011. Poluição atmosférica e internações hospitalares por doenças respiratórias em crianças e adolescentes em Cubatão, São Paulo, Brasil, entre 1997 e 2004, Cadernos de Saúde Pública, 27, 2242-2252.

Kaplan, S. A. 1980. Neo-Eskimo Occupations of the Northern Labrador Coast, Arctic, 33. 
Leorri, E., Mitra, S., Irabien, M. J., Zimmerman, A. R., Blake, W. H., and Cearreta, A. 2014. A 700 year record of combustion-derived pollution in northern Spain: tools to identify the Holocene/ Anthropocene transition in coastal environments, Sci Total Environ, 470-471, 240-247.

Martin, L., Suguio, K., and Flexor, J. M. 1986. Shell middens as a source for additional information in Holocene shoreline and sea-level reconstruction: examples from the coast of Brazil. In: Sea-Level Research: a manual for the collection and evaluation of data, van de Plassche, O. (Ed.), Springer, The Hague.

Martinez, S., Mahiques, M. M., and Burone, L. 2013. Mollusks as indicators of historical changes in an estuarine-lagoonal system (Cananeia-Iguape, SE Brazil), The Holocene, 23, 888-897.

Martins, C. C., Bicego, M. C., Mahiques, M. M., Figueira, R. C., Tessler, M. G., and Montone, R. C. 2010. Depositional history of sedimentary linear alkylbenzenes (LABs) in a large South American industrial coastal area (Santos Estuary, Southeastern Brazil), Environ Pollut, 158, 3355-3364,

Martins, C. C., Bicego, M. C., Mahiques, M. M., Figueira, R. C., Tessler, M. G., and Montone, R. C. 2011. Polycyclic aromatic hydrocarbons (PAHs) in a large South American industrial coastal area (Santos Estuary, Southeastern Brazil): sources and depositional history, Mar Pollut Bull, 63, 452-458.

Martins, C. C., Mahiques, M. M., Bicego, M. C., Fukumoto, M. M., and Montone, R. C. 2007. Comparison between anthropogenic hydrocarbons and magnetic susceptibility in sediment cores from the Santos Estuary, Brazil, Mar Pollut Bull, 54, 240-246.

Martins, V. A., Dias, J. A., Bernardes, C., Rubio, B., Bernabeu, A., Rey, D., Soares, A. M., Sobrinho, F., Laut, L. M., Frontalini, F., Terroso, D., Miranda, P., Fernández-Fernández, S., Rodrigues, M. A., Figueira, R., Sousa, S., Amaral, P., Mahiques, M., and Rocha, F. 2013. The ITRAX core scanner, a useful tool to distinguish anthropicvs.climatic influences in lagoon of Aveiro (N Portugal), Journal of Coastal Research, 65, 70-75.

Menzel, D. 1959. The Inca Occupation of the South Coast of Peru, Southwestern Journal of Anthropology, 15, 125-142.

Muehe, D. 1998. O litoral brasileiro e sua compartimentação. In: Geomorfologia do Brasil, Cunha, S. B. and Guerra, A. T. (Eds.), Bertrand Brasil, Rio de Janeiro.

Neves, W. A., Hubbe, M., Okumura, M. M., Gonzalez-Jose, R., Figuti, L., Eggers, S., and De Blasis, P. A. 2005. A new early Holocene human skeleton from Brazil: implications for the settlement of the New World, J Hum Evol, 48, 403-414.

Saito, R. T., Figueira, R. C., Tessler, M. G., and Cunha, I. I. L. 2001. Journal of Radioanalytical and Nuclear Chemistry, 249, 257261.

Santos, I. R., Burnett, W. C., and Godoy, J. M. 2008. Radionuclides as tracers of coastal processes in Brazil: review, synthesis, and perspectives, Brazilian Journal of Oceanography, 56.

Scheel-Ybert, R., Afonso, M. C., Barbosa-Guimarães, M., Gaspar, M. D., and Ybert, J.-P. 2009. Considerações sobre o papel dos sambaquis como indicadores do nível do mar, Quaternary and Environmental Geosciences, 1.

Steffen, W., Crutzen, P. J., and McNeill, J. R. 2007. The Anthropocene: Are Humans Now Overwhelming the Great Forces of Nature, AMBIO: A Journal of the Human Environment, 36, 614-621.
Stringer, C. 2000. Palaeoanthropology. Coasting out of Africa, Nature, 405, 24-25, 27.

Tramonte, K. M., Figueira, R. C., de Lima Ferreira, P. A., Ribeiro, A. P., Batista, M. F., and de Mahiques, M. M. 2015. Environmental availability of potentially toxic elements in estuarine sediments of the Cananeia-Iguape coastal system, Southeastern Brazil, Mar Pollut Bull, doi: 10.1016/j.marpolbul.2015.12.011, 2015.

Turra, A., Manzano, A. B., Dias, R. J., Mahiques, M. M., Barbosa, L., Balthazar-Silva, D., and Moreira, F. T. 2014. Three-dimensional distribution of plastic pellets in sandy beaches: shifting paradigms, Sci Rep, 4, 4435.

Uchoa, D. P. and Garcia, C. D. R. 1983. Cadastramento dos Sitios Arqueologicos da Baixada Cananeia-Iguape, Litoral do Estado de Sao Paulo, Brasil, Revista de Arqueologia, 1, 19-29.

Vautz, W., Pahl, S., Pilger, H., Schilling, M., and Klockow, D. 2003. Deposition of trace substances via cloud droplets in the Atlantic Rain Forest of the Serra Do Mar, São Paulo State, SE Brazil, Atmospheric Environment, 37, 3277-3287.

Waters, C. N., Zalasiewicz, J., Summerhayes, C., Barnosky, A. D., Poirier, C., Galuszka, A., Cearreta, A., Edgeworth, M., Ellis, E. C., Ellis, M., Jeandel, C., Leinfelder, R., McNeill, J. R., Richter, D., Steffen, W., Syvitski, J., Vidas, D., Wagreich, M., Williams, M., Zhisheng, A., Grinevald, J., Odada, E., Oreskes, N., and Wolfe, A. P. 2016. The Anthropocene is functionally and stratigraphically distinct from the Holocene, Science, 351, $\operatorname{aad} 2622$.

Wichers, C. A. M. o. 2010. Mosaico paulista: guia do patrimônio arqueológico do estado de São Paulo, Zanettini Arqueologia, São Paulo.

Zalasiewicz, J., Waters, C. N., Ivar do Sul, J. A., Corcoran, P. L., Barnosky, A. D., Cearreta, A., Edgeworth, M., Gałuszka, A., Jeandel, C., Leinfelder, R., McNeill, J. R., Steffen, W., Summerhayes, C., Wagreich, M., Williams, M., Wolfe, A. P., and Yonan, Y. 2016. The geological cycle of plastics and their use as a stratigraphic indicator of the Anthropocene, Anthropocene, doi: 10.1016/j.ancene.2016.01.002, 2016.

Zalasiewicz, J., Waters, C. N., Williams, M., Barnosky, A. D., Cearreta, A., Crutzen, P., Ellis, E., Ellis, M. A., Fairchild, I. J., Grinevald, J., Haff, P. K., Hajdas, I., Leinfelder, R., McNeill, J., Odada, E. O., Poirier, C., Richter, D., Steffen, W., Summerhayes, C., Syvitski, J. P. M., Vidas, D., Wagreich, M., Wing, S. L., Wolfe, A. P., An, Z., and Oreskes, N. 2015. When did the Anthropocene begin? A mid-twentieth century boundary level is stratigraphically optimal, Quaternary International, 383, 196-203.

Zanardi, E., Bícego, M. C., de Miranda, L. B., and Weber, R. R. 1999. Distribution and Origin of Hydrocarbons in Water and Sediment in São Sebastião, SP, Brazil, Marine Pollution Bulletin, 38, 261267.

Zembruscki, S. G. 1979. Geomorfologia da margem continental sul brasileira e das bacias oceânicas adjacentes. In: Geomorfologia da margem continental brasileira e áreas oceânicas adjacentes, Chaves, H. A. F. (Ed.), 7, Petrobrás, Rio de Janeiro. 